\title{
KEGIATAN FIELDSTUDY DALAM PEMBENTUKAN KOMPETENSI PROFESIONAL CALON GURU GEOGRAFI
}

\author{
Aris Munandar', Enok Maryani', Dede Rohmat ${ }^{2}$, Mamat Ruhimat ${ }^{2}$ \\ ${ }^{1}$ Dosen FIS UNJ \\ ${ }^{2}$ Dosen Pasca Sarjana UPI \\ Arisbrebes77@gmail.com
}

\begin{abstract}
The purpose of this study is to measure the formation of professional competencies in field study activities. The research was conducted on students who conducted field studies with the names PKL (Field Lecture Practices) at UNJ and KKL (Field Work Lectures) at UPI. There were 120 samples from 580 participants with sample quota with each of 20 students from 6 groups - measurement of professional competence by using multiple choice questions, 30 questions. Questions were constructed from the courses taken by participants in semesters 2, 4 and 6. The test results showed an average value of 56.84 with the lowest score of 44 and the highest of 77. The test results showed more in the medium category; there were no lows and fewer with the high category. The researcher concludes that professional competence in mastering the material has a low relationship. Professional competence in the form of knowledge is formed from other activities such as teaching in the classroom.

Keywords: Field study, competence, professionals
\end{abstract}

\begin{abstract}
Abstrak
Tujuan dari penelitian ini untuk mengukur pembentukan kompetensi professional dalam kegiatan fieldstudy. Penelitian dilakukan terhadap mahasiswa yang melakukan fieldstudy dengan nama PKL (Praktek Kuliah Lapangan) di UNJ dan KKL (Kuliah Kerja Lapangan) di UPI. Jumlah sampel 120 dari 580 peserta dengan kuota sampel dengan masing-masing 20 mahasiswa dari 6 kelompok. Pengukuran kompetensi profesional dengan meggunakan instrument soal pilihan ganda, 30 soal. Soal dikontruksi dari matakuliah yang sudah diambil peserta di semester 2, 4 dan 6. Hasil tes menunjukan nilai rata-rata 56,84 dengan nilai terendah 44 dan tertinggi 77. Hasil tes menunjukan lebih banyak pada kategori sedang, tidak ada yang rendah dan sedikit dengan kategori tinggi. Peneliti berkesimpulan kompetensi profesional penguasaan materi memiliki hubungan yang rendah. Kompetensi profesional berupa pengetahuan terbentuk dari kegiatan lain seperti pengajaran dikelas.

Kata kunci : Fieldstudy, kompetensi, profesional
\end{abstract}

\section{PENDAHULUAN}

Guru yang profesional perlu dikembangkan, karena guru memiliki peranan yang penting dalam pembentukan kualitas sumber daya manusia (Muhson, 2004). Guru yang profesional menjadi penting karena guru yang terlibat langsung dalam proses pembelajaran di kelas. Guru dituntut memiliki beberapa kemampuan dan kompetensi tertentu sebagai bagian dari profesioanalisme guru (Suryanto dkk, 2013, hlm 1). Guru dengan segala hak dan kewajibannya menjalankan profesi mempersiapkan peserta didik yang berkualitas. 
Kualifikasi guru geografi di Numan Adamawa (Nigeria) tidak memiliki kemampuan mengajar (Estawul, 2016, hlm 138). Lebih dari seperempat guru geografi diluar pulau Jawa diajarkan oleh guru yang berlatar belakang bukan geografi, sehingga ketrampilan dan pengetahuan geografi yang diajarkan tidak benar (Adikosusmo, 1990, Grabber. 2000. hlm.101). Guru geografi harus diajarkan oleh guru yang berlatar belakang geografi dari sebuah satuan pendidikan yang berkualitas. Perlu dikembangkan program pendidikan guru yang serasi dan memudahkan pembentukan guru yang berkualifikasi profesional (Hamalik, 2009. hlm.1)

$$
\text { Kompetensi merupakan }
$$
pengetahuan, ketrampilan dan nilai dasar yang direfleksikan dalam kebiasaan berpikir dan bertindak.(Zuldafrial, dkk, 2004, hlm 44). Kompetensi guru merupakan gambaran tentang apa yang harus dilakukan seorang guru dalam melaksanakan pekerjaannya baik berupa kegiatan, perilaku maupun hasil yang ditunjukan dalam proses belajar mengajar.(Suryanto dkk, 2013, hlm.39).Jadi kompetensi guru merupakan kemampuan dalam berpikir bertindak yang harus dimiliki oleh seorang guru baik dilingkungan sekolah maupun dimasyarakat.

Kompetensi guru harus dimiliki oleh setiap guru dalam jenjang pendidikan apapun. kompetensi guru meliputi : kompetensi profesional, kompetensi kepribadian, kompetensi kemasyarakatan. Ketiga kompetensi harus dimiliki saling terkait dalam diri guru. Guru yang terampil mengajar tentu harus memiliki pribadi yang baik dan mampu melakukan social adjustment. (Hamalik, 2009, hlm 34).

Kegiatan serupa dengan fieldstudy yaitu fieldwork. Fieldwork dapat meningkatkan pemahaman pembelajaran yang dapat mengembangkan secara spesifik, transfer keterampilan, mendorong belajar lebih aktif dan menghubungkan teori dengan dunia nyata (Hope, 2009, hlm 169). Fieldwork memberikan kesempatan untuk belajar riil yang dapat meningkatkan pemahaman konsep geografi dan mengembangkan keterampilan yang spesifik (HMI, 1992). Penelitian yang lain menghubungkan antara fieldwork dan dorongan belajar peserta didik yang memberikan keuntungan dalam pendidikan. 
Adanya hubungan yang efektif antara respon peserta didik dalam hal emosi dan nilai pembelajaran yang lebih mendalam ketika dilakukan fieldstudy (Fuller et al., 2006). Fieldstudy dalam bentuk KKL di Universitas Negeri Malang meningkatkan minat dalam belajar geografi (Arinta, 2016, hlm 1665).

Pembentukan kompetensi dapat dilakukan dalam kegiatan pembelajaran yang dilakukan didalam kelas maupun diluar kelas. Salah satu pembelajaran diluar kelas yaitu fieldstudy. Rangkain kegiatan fieldstudy akan membentuk kompetensi guru karena dalam kegiatan ini menyangkut akivitas praktikum dari beberapa matakuliah. Praktikum yang dilakukan diluar kelas, menuntut keaktifan peserta dalam perencanaan sampai pasca pelaksanaan. Rangkaian kegiatan ini akan membentuk pengetahuan peserta yang termasuk dalam kompetensi profesional.

\section{METODE PENELITIAN}

Penelitian ini menggunakan metode deskriptif survey. Populasi penelitian semua mahasiswa prodi pendidikan Geografi FIS UNJ dan UPI, berjumlah 588 orang. Mahasiswa ini mengambil matakuliah PKL/KKL yang didalamnya terdapat kegiatan fieldstudy di semester 2, 4 dan 6. Sampel yang digunakan dengan kuota sampling, yaitu dengan mengambil 20 dari setiap kelompok pelaksanaan fieldstudy (ada 6 kelompok fieldstudy). Total sampel yang digunakan 120 mahasiswa.

Instrument yang digunakan dengan tes pilihan ganda sebanyak 30 soal, dengan mengacu pada mata kuliah yang sudah ditempuh oleh masingmasing peserta. Instrumen tes digunakan untuk mengetahui kemampuan penguasaan materi peserta. Pembuatan soal mengacu pada 3 kelompok fieldstudy. Penyusunan sesuai dengan semester diharapkan peserta sudah mendapatkan konten materi sesuai dengan kelompok pelaksanaan fieldstudy. Menghindari pertanyaan yang konten materi belum diajarkan (Arinta, 2016).

\section{HASIL DAN PEMBAHASAN}

Kompetensi profesional mencangkup kemampuan guru menguasai materi bidang studi mencangkup penguasaan subtansi keilmuan yang menaungi materi kurikulum mata pelajaran. secara terperinci kompetensinya 1) memahami struktur, konsep, dan metode keilmuan yang menaungi dan koheren dengan 
materi ajar; 2) mamahami hubungan konsep antar matapelajaran terkait; 3) menetapkan konsep-konsep keilmuan dalam proses belajar mengajar.

Memperdalam pengetahuan dengan berbagai cara seperti formal melalui jenjang pendidikan, maupun non formal mengikuti kegiatan seminar, pelatihan, keikutsertaan dalam kegiatan ilmiah, membaca buku jurnal penelitian. Penguasaan kemampuan akademik yang komprehensif melalui tes kemampuan berupa ujian tertulis baik berbentuk obyektif, esai, pemecahan masalah, serta ujian kinerja (Zuldrafial, 2014, hlm. 164). Penelitian ini menggunakan ujian tertulis berbentuk pilihan ganda untuk melihat sejauh mana pemahaman materi keilmuan.

Secara langsung peserta dituntut untuk mengetahui konsep/konten yang berkaitan dengan obyek kajian fieldstudy yang mengacu pada matakuliah yang sudah ditempuh masing-masing peserta. Tes pilihan ganda dengan jumlah 30 soal, untuk kelompok kegiatan PKL/KKL. Soal I untuk PKL/KKL 1 semester 2, Soal II untuk PKL/KKL II semester 4 dan soal III untuk PKL/KKL III semester 6 .

Kegiatan fieldstudy meliputi aktivitas pra kegiatan, pelaksanaan dan pasca kegiatan Rangkaian kegiatan ini melibatkan peserta baik secara fisik dan intelektual. Aktivitas pra meliputi rapatrapat pembentukan panitia, membuat proposal, membuat instrument., membuat perijinan. Aktivitas pelaksanaan dari berangkat kelokasi tujuan, pengumpulan data, pengolahan data, presentasi data, dan kembali dari lokasi lapangan. Aktivitas pasca meliputi membuat laporan, mempresentasikan hasil akhir, membuat artikel/poster/standing baner.

Rangkaian kegiatan ini akan melibatkan peserta secara penuh dengan bekal pengetahuan, sikap, keterampilan yang diperoleh didalam kelas. Aktivitas akademik ini juga akan membentuk kompetensi profesional dari peserta. Domain kognitif/pengetahuan yang menjadi kajian dalam penelitian ini mengacu pada kompetensi profesional. Berikut grafik hasil tes pengetahuan secara umum 


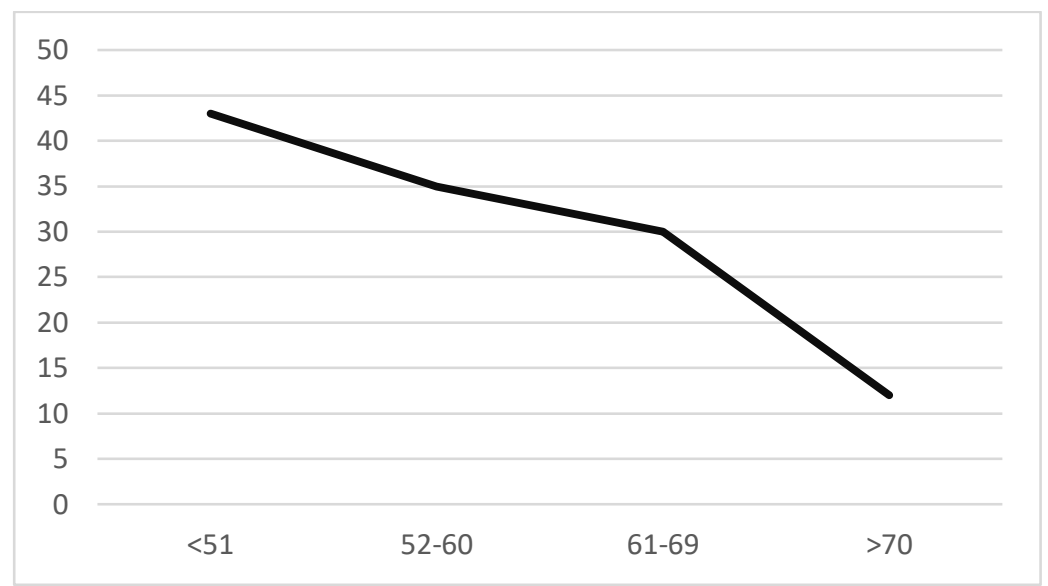

Gambar 1. Grafik hasil tes pengetahuan secara umum

Hasil tes menunjukan nilai rata-rata 56,84 dengan nilai terendah 44 dan tertinggi 77. Mengacu kriteria kelulusan pada kegiatan PPG Prajabatan 75\% (Zuldafrial, 2014, hlm 65). Perhitungan presentasi hasil tes memiliki nilai yang rendah. Peneliti berkesimpulan kompetensi profesional penguasaan materi memiliki sumbangan yang rendah dalam pembentukan kompetensi profesional, khususnya konten materi. Hasil tes jika digambarkan dalam grafik, disebut kurva juling positif karena ekornya dikanan, menunjukan soal terlalu sukar (Daryanto, 2008, hlm.212). Kompetensi profesional berupa konten materi akan diperkaya dari kegiatan lain seperti pengajaran dikelas. Pengetahuan calon guru diperoleh dari pendidikan prajabatan (Solbarkke, 2014, hlm 10).

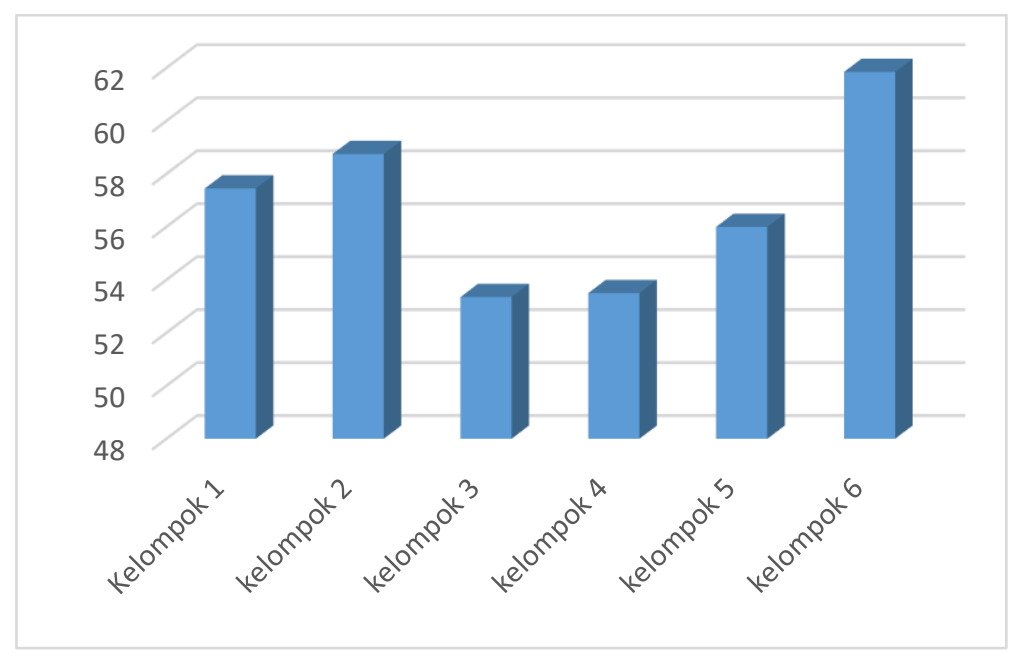

Gambar 2. Grafik Nilai Rata-rata Kelompok 
Rata-rata nilai kelompok sedikit berbeda, rata-rata tertinggi ada dikelompok 6 yaitu 61.85 dan rata-rata terendah ada dikelompok 3 yaitu 53,35. Tingginya ratarata nilai dikelompok 3 disebabkan pelaksanaan fieldstudy yang terintegrasi dari tiap tahapannya yaitu pada kelompok 2, 4 dan 6 pada Departemen Pendidikan
Geografi UPI. Pada kelompok geografi UNJ 1 menekankan pada materi geografi fisik, kelompok 3 menekankan pada materi geografi sosial dan kelompok 5 pada materi integrasi antara fisik dan sosial. Pengintegrasian diindikasikan memiliki nilai lebih dalam kompetensi profesional.

Tabel 2. Materi Kajian KKL di UPI

\begin{tabular}{llllll}
\hline \multicolumn{1}{c}{ Tahapan } & $\begin{array}{c}\text { Identifikasi } \\
(\boldsymbol{\%})\end{array}$ & $\begin{array}{c}\text { Klasifikasi } \\
(\boldsymbol{\%})\end{array}$ & $\begin{array}{c}\text { Analisis } \\
(\boldsymbol{\%})\end{array}$ & $\begin{array}{c}\text { Pemecahan } \\
\text { masalah }(\boldsymbol{\%})\end{array}$ & $\begin{array}{l}\text { Total } \\
(\boldsymbol{\%})\end{array}$ \\
\hline KKL I & 60 & 20 & 15 & 5 & 100 \\
\hline KKL II & 50 & 20 & 15 & 15 & 100 \\
\hline KKL III & 20 & 20 & 25 & 35 & 100 \\
\hline
\end{tabular}

Sumber : Survey pendahuluan, 2018

Rendahnya pengetahuan yang diperoleh peserta dari kegiatan fieldstudy dengan nama PKL/KKL ada tiga indikasi, yaitu 1). perbedaan karakterisik dari masing-masing kelompok dalam penekanan materi fieldstudy, 2) soal yang diberikan terlalu sukar bagi peserta,3) banyaknya materi yang harus dikuasai peserta dalam mengaplikasikan/menerapkan dalam kegiatan fleldstudy. Perlu dibuat 6 paket soal yang sesuai dengan karakteristik materi dari masing-masing kelompok fieldstudy. Soal harus kontekstual sesuai dengan lokasi pelaksanaan PKL/KKL. Apabila lokasi di pegunungan maka soal-soal berkaitan dengan pegunungan dan materi yang diajarkan dikelas.

Pembimbing perlu melihat ulang Rencana Pembelajaran Semester, kompetensi yang diperoleh setelah peserta melakukan kegiatan fieldstudy, sehingga penilaian aspek kognitif sesuai dengan pelaksanaan kegiatan lapangan. Perlu juga diadakan evaluasi untuk melngukur sejauh mana program dapat berjalan sesuai dengan ketentuan. 
Jurnal Parameter Volume 31 No. 1

DOI : doi.org/10.21009/parameter.311.01

P-ISSN : 0216-261X E-ISSN : 2620-9519

\section{PENUTUP}

.Kegiatan fieldstudy dapat memberikan pengetahuan kepada peserta kurang maksimal, hasil tes dengan pilihan ganda menunjukan nilai rata-rata peserta 56,84 dengan nilai terendah 44 dan tertinggi 77. Pengintegrasian materi dalam pelaksanaan fieldstudy memberikan perbedaan dalam rata-rata perolehan kelompok fieldstudy. Kelompok 6 fieldstudy memiliki rata-rata yang lebih tinggi dibanding dengan kelompok lain. Tingginya nilai rata-rata pada kelompok 6 diindikasikan karena peserta sudah terbiasa mengintegrasikan konsep konsep geografi fisik dan sosial secara bersama-sama sejak mengikuti kegiatan fieldstudy. Perlu dibuat soal-soal yang tidak berpatokan pada matakuliah yang pernah diambil perserta juga sesuai dengan karakteristik materi masing-masing pelaksanaan fieldstudy.Pengujian soal disesuikan dengan titikberat masingmasing kelompok fieldstudy

\section{DAFTAR PUSTAKA}

Arianta, Dicky, sugeng Utaya, I Komang Astina, (2016) Implementasi Pembelajaran Kuliah Kerja Lapangan dalam Meningkat Minat Belajar Mahasiswa Program Pendidikan Geografi Universitas Negeri Malang,
Jurnal Pendidikan Vol. 1 No 8

bulan Agustus 2016

Daryanto, (2008), Evaluasi Pendidikan, Jakarta, Rineke Cipta

Estawul, Suwopoleme Silas Linus K.

Sababa, Jacob Filgona, (2016)

Effect Of Fieldtrip Strategy on

Senior Secondary Scholl

Students' Academic

Achievment In Geography In

Numan Educational Zona,

Adamawa State, Nigeria.

European Journal of Education

Studies Volume 2 | Issue

$12 \mid 2016$

Fuller, Sally Edmondson, Derk France, David Higgit \& Ilkka Ratinen (2006). International Perspectives on the Effectiveness of Geography Fieldwork for Learning, Taylor \& Francis Journal of Geography in Higher Education, Vol. 30, No. J, 89-101. March 2006

Gerber, Rod. Goh Kim Chuan (2000). Fieldwork in Geography: Reflection, Perspektives and Actions, Springer Scince Busines Media B.V 
Hamalik, Oemar (2009), Pendidikan

Guru Berdasrkan Pendekatan

Kompetensi, Bumi Aksara

Jakarta

HMI (Her Majesty's Inspectorate) (

1992) A Survey of Geography

Fieldwork in Degree Courses.

Sler 1990- Summer 1991: a

Report by HM/. Report 9/92/NS

(Sranmore: Her Majestyv

Inspectorate. Department of

Education and Science).

Hope, Max (2009) The Importance of

Direct Experience : $A$

Philosophical Defence of

Filedwork in Human

Geografphy, Journal Of

Geography in Higher Education

Vol. 33, No 2, 169-182, May

2009, Rouledge

Muhson, Ali ,(2004). Meningkatkan

Profesionalisme Guru : Sebuah

Harapan Jurnal Ekonomi dan

Pendidikan volume 2 No 1

Agustus 2004
Mulyantari. (2005). "Kuliah Kerja Lapangan (KKL) I Geografi Sebagai Salah Satu Metode Pembelajaran Kontekstual dan Pengaruhnya Terhadap Prestasi Belajar Mahasiswa Pendidikan Geografi“". (skripsi). Jurusan Geografi. FIS. UNES. Semarang

Mulyasa, E. (2008). Standar Kompetensi dan Sertifikasi Guru. Bandung: Remaja RosdaKarya.

Solbrekke, T. D., \& Englund, T. (2014). Certification of teachers: Tensions in a new signature reform. Professions and Professionalism, 4(2), 1-13.

Suryanto, Asep Jihad, 2013, Menjadi Guru Profesional strategi Meningkatkan Kualifikasi dan Kualitas Guru di Era Globalisasi, Jakarta, Essensi,

Zuldafrial, M. Lahir, 2014, Profesi Kependidikan Guru Dalam Perspektif Undang-Undang Nomor 14 Tahun 2005, Yogyakarta, Media Perkasa 